\title{
IDENTIFICATION OF POTENTIAL RAINWATER HARVESTING SITES FOR THE SUSTAINABLE MANAGEMENT OF A SEMI-ARID WATERSHED ${ }^{\dagger}$
}

\author{
R. REJANI ${ }^{1 *}$, K.V. RAO ${ }^{1}$, CH.SRINIVASA RAO ${ }^{1}$, M. OSMAN $^{1}$, K. SAMMI REDDY $^{1}$, \\ BIJU GEORGE ${ }^{2}$, G.S. PRATYUSHA KRANTHI ${ }^{1}$, G.R. CHARY ${ }^{1}$, M.V. SWAMY ${ }^{3}$ AND \\ P. J. RAO ${ }^{3}$ \\ $=$ \\ ${ }^{1}$ Indian Council of Agricultural Research (ICAR) - Central Research Institute for Dryland Agriculture \\ (CRIDA), Hyderabad, India \\ ${ }^{2}$ International Centre for Agricultural Research in the Dry Areas (ICARDA), Cairo, Egypt \\ ${ }^{3}$ Modern Architects for Rural India (MARI), Warangal, India
}

\begin{abstract}
In the present study, the potential locations to construct different water harvesting structures in a semi-arid watershed located at Goparajpalli, in Southern India was derived using GIS in three stages. The locations were first identified based on land use land cover, land slope, rainfall characteristics, soil texture and soil depth. Then the number of structures and suitable semi-arid rainfed regions have limitations in the runoff potential availability; these locations were further optimized based on the runoff available after the in-situ water conservation and storage in the existing water harvesting structures. The surplus runoff volume available in a normal year after the storage was estimated to be $870,000 \mathrm{~m}^{3}$. Suitable locations for 25 rock fill dams (RFD), 74 farm ponds and 5 check dams were identified. These derived sites were validated by exporting to Google Earth and investigated for its suitability with ground truth information. At present, the
\end{abstract}

\footnotetext{
† Identification des sites de récupération des eaux de pluie pour la gestion durable d'un bassin versant semi-aride

* Correspondence to: R. Rejani, Central Research Institute for Dryland Agriculture (CRIDA). Hyderabad, Telangana, India. E-mail: rrejani@rediffmail.com/rrejani10@gmail.com.
}

This is the author manuscript accepted for publication and has undergone full peer review but has not been through the copyediting, typesetting, pagination and proofreading process, which may lead to differences between this version and the Version of Record. Please cite this article as doi: 10.1002/ird.2101

This article is protected by copyright. All rights reserved. 
number of structures existing are more than the optimum number of structures derived, but are with less storage capacity. Hence these structures such as farm ponds located at potential sites are recommended for de-siltation and renovation by increasing the size along with lining so that they can be utilized for rainwater harvesting and supplemental irrigation. This methodology for identification of potential locations for water harvesting structures is less time consuming, more precise and can be utilized for the planning of large catchments to improve the water availability and productivity.

Keywords: GIS; remote sensing; runoff potential; water harvesting structures.

\section{RÉSUMÉ}

Dans la présente étude, les emplacements potentiels pour construire des structures de collecte de l'eau dans un bassin versant semi-aride située à Goparajpalli, en Inde du Sud ont été déterminés en trois étapes en utilisant un SIG. Les lieux ont d'abord été identifiés sur la base de la couverture de l'utilisation des terres, de la pente du terrain, des caractéristiques des précipitations, de la texture et de la profondeur du sol. Ensuite, le nombre de structures de collecte et l'aptitude de la région semi-aride au stockage sont limités par le potentiel de genèse du ruissellement. Nous avons optimisé ces deux paramètres en évaluant l'écoulement disponible après la conservation et le stockage de l'eau in situ dans les structures de collecte d'eau existantes. L'excédent disponible après stockage d'eaux de ruissellement en année normale a été estimé à $870000 \mathrm{~m}^{3}$. Des endroits appropriés pour 25 barrages en enrochement compacté (RFD), 74 étangs de ferme et 5 barrages de correction ont été identifiés. Ces sites ont été validés par l'exportation vers Google Earth et une enquête de vérité terrain. À l'heure actuelle, les structures existantes sont plus nombreuses que le nombre optimal de structures déterminées par la présente optimisation, mais sont d'une capacité de stockage moindre. Par conséquent, ces structures telles que les étangs de ferme situés sur les sites identifiés sont recommandés pour le dévasement et l'augmentation de la superficie étanchéifiée de sorte qu'ils puissent être utilisés pour collecter l'eau de pluie et l'irrigation d'appoint. Cette méthodologie pour l'identification des sites potentiels pour les structures de collecte de l'eau est rapide et précise, et peut être utilisée pour la planification des grands bassins versants pour améliorer la disponibilité de l'eau et de la 
productivité.

MOTS-CLES : SIG ; télédétection ; potentiel de ruissellement ; structures de collecte d'eau.

\section{INTRODUCTION}

Soil and water are two important vital resources needed for the survival of plants and animals. The optimal management of these two resources are very essential for the sustainability of the ecosystems. The annual per capita water availability in India has decreased from $5180 \mathrm{~m}^{3}$ in 1951 to $1650 \mathrm{~m}^{3}$ in 2007 . It is projected to decrease further to $1340 \mathrm{~m}^{3}$ by 2025 and $1140 \mathrm{~m}^{3}$ by 2050, thereby approaching a water scarce condition of less than $1000 \mathrm{~m}^{3}$ per year (Ministry of Water Resources (MOWR), 2008). The growing industries and population coupled with climatic variability and irrigation practices caused over-exploitation of groundwater resources leading to decline of water table in several parts of India (Kadam et al., 2012; Massuel et al., 2013). According to the Central Ground Water Board, 15\% of the administrative blocks are over-exploited and are growing at a rate of 5.5\% per year (Rejani et al., 2015a). Many parts of the country experiences drinking water crisis during summer season. Changing climate scenarios resulting in weather aberrations like delayed/deficit monsoon, high intensity rainfalls of short duration leading to more runoff/erosion and prolonged dry spells leading to crop failure (Srinivasarao et al., 2014). Even in areas with high rainfall, there is limited availability of water during summer season due to low water storage capacity, low infiltration capacity, large fluctuations of precipitation and high evaporative demand (Food and Agriculture Organisation of the United Nations (FAO), 2016). Drought is a natural calamity caused by the failure of rain and it can be minimized by careful planning and operation. In India, around $92 \mathrm{M}$ ha-m of surface runoff drains to oceans and sea after storage in the existing structures (Sharma and Paul, 1998). The water stress prevails in agricultural fields during dry spells can be managed by insitu moisture conservation practices and by harvesting the runoff during good rainy days in water harvesting structures. This harvested water can be utilized for groundwater recharge or for supplemental irrigation during prolonged dry spells and critical crop growth stages.

The in-situ conservation practices consist of soil management and land management practices. The soil management practices are temporary in nature which may last for one crop 
season and could be taken up by farmers themselves. The land management practices are semipermanent in nature and need involvement of external agency for planning and implementation. The soil management practices include conservation furrows, mulching, ridging, tillage, broad based furrow (BBF), soil amendments like tank silt etc. The land management practices include contour bunds, field bunds, graded bunds, small basins, terraces, lock and spill drains, stone bunds etc. Wherever, vegetative and other in-situ erosion control measures are insufficient to handle huge quantities of surface runoff, water harvesting structures are needed (Rejani et al., 2015b). The ex-situ interventions are mainly drainage line treatments or water harvesting structures like check dams, percolation tanks, rock fill dams (RFD), gabion structures etc. Farm ponds could be constructed along the drainage lines or on catchments without drainage lines, but have sufficient runoff potential for water harvesting. Farm ponds when constructed in loose textured soils requires lining to minimize the seepage whereas in clayey soils having negligible seepage may not require lining. However, unlined farm ponds in soil having higher seepage can be utilized to recharge the aquifers. The implementation of these soil and water management practices has resulted in increasing the water availability, net cultivated area, area under supplementary irrigation, productivity of crops and improved the groundwater levels (Prasad et al., 2014).

The selection of proper structures for a specific location and its optimal planning for rainwater harvesting are key factors for effective and economic control of runoff and soil loss. Since, the construction of water harvesting structures is expensive, its site selection needs precision. The under-performance and failure of many structures are mainly due to its improper design and construction. In some cases, under treatment of catchment area contributing to runoff can also result in the failure of structures. The identification of potential locations for various soil and water conservation interventions with the help of traditional survey is a difficult task and time consuming work for the planners. Hence, many researchers have used remote sensing and geographical information system (GIS) to find the potential sites for different in-situ and exsitu rainwater harvesting interventions (Ramakrishnan et al., 2008; Chowdary et al., 2009; Srivastava et al. 2010; Shanwad et al., 2011). The GIS helps to handle huge spatial and temporal data for the hydrological modeling and the feature of overlaying maps and its analysis helped to integrate different hydrologic parameters like soil, land use land cover (LULC) and rainfall (Cheng et al., 2006; Ramakrishnan et al., 2009; Nune et al., 2014). Many literatures pertaining to site selection procedures for various water harvesting structures considered 
watershed area, slope, runoff, soil loss, stream orders and various socio-economic aspects (Integrated Mission for Sustainable Development (IMSD). 1995; Geetha et al., 2007; Rejani et al., 2016).

Runoff is the main parameter used to derive the potential rainwater harvesting sites and it depends on daily rainfall, soil type, slope, land treatments, LULC and antecedent moisture condition of the selected region. The data of runoff and soil loss information are scarce in India and are available only from few locations where gauging stations are prevailing. Hence, estimation of runoff is needed for unguaged areas while planning interventions. Among the different runoff estimation methods, Soil Conservation Service Curve Number method is usually followed by researchers and it can be easily integrated with advanced tools like GIS and remote sensing (Nandgude et al., 2014; Rejani et al., 2015a). Many researchers have directly used, modified and evaluated the SCS-CN model (Pandey and Sahu, 2002; Mishra et al., 2008a; Mishra et al., 2008b; Amutha and Porchelvan, 2009; Soulis et al., 2009; Malekani et al., 2014) and estimated runoff. This approach helps to enhance the accuracy of spatial runoff estimations useful for the precise identification of potential sites for the rainwater harvesting structures (Kadam et al., 2012). Site suitability map with good accuracy could be derived by an integrated approach considering remote sensing, GIS and geology of the area (Kumar et al., 2008; Singh et al., 2009; Ramakrishnan et al., 2009; Pandey et al., 2011; Patel et al., 2013; Balakrishna and Jayaramu, 2014). The watershed based approach for planning of site specific interventions will help to conserve soil and water resources which in turn enhances the land productivity (Saptarshi and Raghavendra, 2009). This approach helps to analyze different runoff related parameters like topography, LULC, soil properties, rainfall etc. The main objective of this study is to standardize the methodology to determine the optimal number and potential locations for constructing different water conservation structures for the sustainability of semi-arid watersheds of this region.

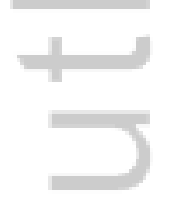

\section{MATERIALS AND METHODS}

\section{Study area}

The Goparajpalli watershed covering an area of 1660 ha, lies in Warangal District, a semi-arid region of Southern India (Figure 1). It is located between $17^{\circ} 46^{\prime}$ to $17^{\circ} 50^{\prime} \mathrm{N}$ and $79^{\circ} 4^{\prime}$ 
to $79^{\circ} 8^{\prime} \mathrm{E}$ in Telangana State. The cultivation of crops mainly depends on seasonal rainfall and more than 90 percent is under rainfed agriculture. The watershed is characterized by moderate to very deep soil with clayey and cracking clayey texture. Almost all the stream networks in this region are rainfed and remains dry during summer. The average rainfall of this watershed is around $735 \mathrm{~mm}$ per annum and $80 \%$ of it occurs during June to September months (Rejani et al., 2015a). The temperature rises up to $45{ }^{\circ} \mathrm{C}$ in summer and drops below $11{ }^{\circ} \mathrm{C}$ in winter. This region is affected by weather aberrations like delayed/deficient monsoon and drought. Hence, ground water is the major water source and is extracted mainly by drilling bore wells for human consumption, animal rearing and irrigation purpose. According to Central Ground Water Board, the selected watershed in Jangaon Mandal comes under the category of over-exploited groundwater status. The over exploitation of groundwater in this region resulted in declining groundwater levels of around $28 \mathrm{~cm} /$ year during pre-monsoon season (Central Ground Water Board (CGWB), 2013). The land use land cover (LULC) consists of 816 ha under kharif crop, 26 ha under rabi crop, 126 ha under double crop, 320 ha under current fallow, 190 ha under other waste land and 175 ha under scrub land (LULC, 2011-12) (Rejani et al., 2015a). The area under different land use land cover is very important while estimating the runoff potential and for deciding the suitable interventions. The major crops cultivated in this watershed are paddy, cotton, maize, pulses and vegetables. Variable climate with weather aberrations affects the optimal growth of plants resulting in low crop productivity in this area and rainwater harvesting and its utilization is a climate resilient adaptation technique. Hence, the present work was undertaken to identify suitable locations for different water harvesting structures for the selected watershed.

\section{Spatial database}

In the present study, different thematic layers of LULC, soil map, Digital Elevation Model (DEM) derived from contour map, slope map and Aphrodite rainfall data (1951-2007) was used. The contour lines, drainage lines, stream orders and surface water bodies were digitized from the toposheet prepared by Survey of India (1:25000). Then the stream networks and surface water bodies were edited by overlaying Google Earth as base map in GIS. The thematic layer of slope was derived from the DEM using ArcGIS (Figure 2). Soil map from National Bureau of Soil Survey and Land Use Planning (1:50000) and the LULC map (1:50000) from National Remote Sensing Centre was used (Rejani et al., 2015a). 
GIS model for the planning soil and water conservation interventions

The potential sites for different soil and water conservation interventions were planned in three stages (Figure 3).

\section{Stage I: Site suitability}

Location specific identification of suitable sites with the aid of GIS involves the application of a set of primary criteria such as soil, topographic and hydrologic parameters like rainfall and runoff. In the present study, a set of soil and water conservation interventions like rock fill dams, farm ponds and check dams were suggested for the watershed taking into account of the watershed characteristics and aforesaid parameters. The guidelines presented in Tables 1 and 2 were followed at Stage I for the planning of suitable sites for water harvesting structures and other in-situ interventions.

Stage II: Determination of optimum number of structures

The precise locations and optimum number of structures were determined at Stage II based on the slope, vertical interval, horizontal interval.

Singh et al., 1997 reported Cox's formula for calculation of vertical interval.

$V I=(X S+Y) * 0.3$

where $\mathrm{VI}=$ vertical interval; $\mathrm{X}=$ rainfall factor; $\mathrm{S}=$ slope $(\%)$ and $\mathrm{Y}=$ infiltration and crop cover factor. The rainfall analysis showed that $82.0 \%$ of the rainfall in the watershed occurs with intensities less than $7.5 \mathrm{~mm} /$ day (moderate rainfall). The selected study area has moderate rainfall and hence the rainfall factor (X) was selected as 0.6 and infiltration and crop cover factor $(\mathrm{Y})$ as 2.0 .

The optimum number of structures (NS) for drainage lines of watershed was determined using Eqn. 2. For constructing soil and water conservation structures, at least 20 to $30 \mathrm{~m}$ length of flat areas are needed depending upon the size of the structures (Rao, 2003). 
$N S=\frac{(L-20)}{H I}+1$

where NS = number of structures; $\mathrm{L}=$ length of drainage channel $(\mathrm{m}) ; \mathrm{HI}=$ horizontal interval (m)

$H I=\frac{V I}{S} * 100$

Stage III: Estimation of runoff and potential sites for structures

In semi-arid regions, runoff potential availability and its temporal variability were considered as alarming factors. Hence, the final locations and number of structures were optimized based on the spatial availability of surplus runoff after in-situ soil moisture conservation. The daily rainfall data for a period of 1951-2007 was analyzed. The number of rainy days, $\%$ rainfall and $\%$ rainy days contributed to rainfalls $<25 \mathrm{~mm} /$ day, 25 to $50 \mathrm{~mm} /$ day, 50 to $75 \mathrm{~mm} /$ day, 75 to $100 \mathrm{~mm} /$ day and more than $100 \mathrm{~mm} /$ day was also estimated. The years were classified into above normal, normal and normal years based on the annual rainfall. The years with annual rainfall $>+19 \%$ of mean annual rainfall was classified as above normal year, 19 to $+19 \%$ as normal year rainfall and $<-19 \%$ as drought years.

\section{SCS CN method}

The SCS CN method (SCS, 1972) was used for predicting daily runoff from Aphrodite rainfall data for a period of 1951-2007 (57 yrs). The maximum retention storage (S) is related to a curve number $(\mathrm{CN})$ and depends on LULC, land treatments, soil and antecedent moisture conditions prevailing in the selected watershed (Rejani et al., 2015a). The annual and average annual runoff potentials were determined from daily runoff values.

The spatial distribution of average annual runoff $(\mathrm{mm})$ was converted to runoff volume by dissolving it using the catchments derived using the Hydro tool. Then the surplus runoff potential was estimated from the total runoff volume by deducting the in-situ soil moisture conserved and storage in the existing structures in a normal year. Subsequently, the potential sites were determined based on the surplus runoff potential available and the locations for various structures identified at Stage II was modified at Stage III. 


\section{Validation of potential sites}

Soil and water conservation interventions like trench cum bunds, water absorption trenches and continuous contour trenches already constructed in the watershed stores around @ $50 \mathrm{~m}^{3}$ water/ha and 13 percolation tanks, one check dam, 24 RFDs and 123 existing farm ponds have the capacity to harvest around $390,000 \mathrm{~m}^{3}$ of water per year. The potential locations identified for constructing the water harvesting structures needs to be validated for its suitability. The accuracy assessment could be carried out by overlying the locations of existing structures identified during ground truth survey on the potential rainwater harvesting map (Ramakrishnan, 2009; Kadam et al., 2012). In this study, the suitability map for potential locations identified at Stage III was converted to .kml file, exported to Google Earth and validated with the locations of existing structures by visual interpretation. The ground truth pertaining to location of existing structures (latitudes and longitudes) was collected during the survey and was exported to GIS for further validation and planning for additional structures. The additional structures needed were planned after deducting the storage of runoff in the existing structures.

\section{RESULTS AND DISCUSSION}

The required thematic layers were integrated in GIS and suitable locations for different interventions were derived using the requisite criteria in three stages described below. The suitable locations were identified based on soil texture, soil depth, LULC, slope of the land, rainfall, runoff availability etc.

\section{Identification of potential locations at Stage I}

The site suitability at Stage I was derived based on slope, soil texture, LULC and rainfall characteristics. Out of the total 1660 ha area of the watershed, more than $95 \%$ of the area was suitable for carrying out different in-situ soil and water conservation interventions and water harvesting structures. More than $60 \%$ of the watershed area was suitable for water harvesting structures like rock fill dams (RFD), farm ponds and check dams (Figure 4). 


\section{Identification of potential sites and optimum number of structures at Stage II}

Different thematic layers of stream orders, soil characteristics and slope maps were integrated in GIS. Then the number of structures was determined based on slope of the land, vertical interval and horizontal interval required between structures (Figure 5). Since, construction of structures need flat areas to minimize the cost of excavation, the locations in the drainage line where slope length more than $20 \mathrm{~m}$ was obtained by intercepting the integrated drainage line and slope polygons in GIS (Figure 6). These suitable locations and the optimum number of structures determined (Figure 6) were applied to derive the map for the potential locations of suitable structures in Stage II. These locations can be directly utilized as potential sites for high rainfall regions where runoff availability for rainwater harvesting is not limited. Out of 57 years, around $75.8 \%$ of the rainfall and $92.1 \%$ of the rainy days occurred was below $25 \mathrm{~mm} /$ day. Around $19.2 \%$ of the daily rainfall and $6.9 \%$ of the rainy days occurred ranged from 25 to $<50 \mathrm{~mm} /$ day and $3.5 \%$ of the rainfall and $0.8 \%$ of the rainy days ranged from 50 to $<75 \mathrm{~mm} /$ day. Extreme rainfall events with more than $75 \mathrm{~mm} /$ day has occurred only 7 times in the watershed during the 57 year period. Since, the selected semi-arid watershed have limitations in the harvestable runoff, the determined locations were further optimized based on the surplus runoff available in a normal year after storage by the in-situ conservation practices and existing water harvesting structures.

\section{Estimation of surplus runoff potential}

The thematic layers of slope, soil, rainfall, LULC were integrated in GIS and the runoff potential estimates corresponding to different hydrologic soil groups, LULC and antecedent moisture conditions were derived by applying SCS CN method. The annual and mean annual runoff potentials were estimated using this daily runoff values. The average runoff in loamy soil varied from 8.7 to $13.1 \%$ and clayey soil varied from 14 to $20 \%$ of the mean rainfall. Out of 57 years, the number of drought, normal and above normal years were 21.1, 59.6 and $19.3 \%$ respectively with a runoff of $7.1,13.9$ and $18.7 \%$ of annual rainfall in clayey soil respectively. Since $59.6 \%$ of the years were normal, spatial runoff during normal year was considered for planning interventions in this study and the average annual rainfall varied from 598 to $878 \mathrm{~mm}$. The surplus runoff potential available for rainwater harvesting was estimated after deducting the storage of approximately @ $50 \mathrm{~m}^{3} / \mathrm{ha}$ by already existing in-situ water conservation measures like trench cum bunds, water absorption trenches, continuous contour trenches etc and the 
storage of $390,000 \mathrm{~m}^{3}$ by water harvesting structures like check dams, rock fill dams, farm ponds, percolation tanks etc. The spatial distribution of the surplus runoff estimated for the entire watershed is presented in Figure 7. It varied from runoff volumes $<1500 \mathrm{~m}^{3}$ to $>10,000$ $\mathrm{m}^{3}$. The surplus runoff volume available in a normal year after the water harvesting by the existing structures from the entire watershed was estimated to be $870,000 \mathrm{~m}^{3}$. The runoff volume was more than $10,000 \mathrm{~m}^{3}$ for four larger catchments covering an area of 174 ha and it ranged from 5000 to $10,000 \mathrm{~m}^{3}$ for 24 catchments with an area of 524 ha, and for the remaining 102 catchments, it was $<5000 \mathrm{~m}^{3}$. Bunds of height 0.3 to $0.5 \mathrm{~m}$ constructed along the boundaries of crop field act as water harvesting structures and the mean annual runoff from the crop field get reduced from 13.9 to $5.2 \%$ of mean annual rainfall by absorbing runoff @ $<10$ $\mathrm{mm} /$ day in the soil itself.

\section{Identification of suitable sites at Stage III and validation}

Based on the surplus runoff potential availability (Figure 7), the potential locations derived in Stage II was further modified in Stage III (Figure 8). The farm ponds and minipercolations tanks were planned with a capacity of $1200 \mathrm{~m}^{3}$ and check dams with $4500 \mathrm{~m}^{3}$. The surplus runoff volume available in a normal year after the existing storage from the entire watershed was considered. Suitable locations for 25 rock fill dams (RFD), 74 farm ponds and 5 check dams were identified (Figure 8). RFDs are small structures constructed along first order drains. The in-situ interventions adopted in the watershed includes water absorption trenches, trench cum bunds and continuous contour trenches. There are 13 percolation tanks, one check dam, 24 RFDs, 123 existing farm ponds available in the watershed which is harvesting 390,000 $\mathrm{m}^{3}$ of water. But the farm ponds are smaller in size with a capacity of $300 \mathrm{~m}^{3}$. Hence, these structures located at potential locations are recommended for renovation by increasing the size from $300 \mathrm{~m}^{3}$ to $1200 \mathrm{~m}^{3}$ or by constructing new farm ponds with lining so that they can be utilized for rainwater harvesting and supplementary irrigation for kharif crops in addition to the existing structures in the watershed.

The suitability of these sites derived using GIS was evaluated by exporting it to Google Earth and further validated using ground truth data collected (Figure 9). The derived sites and sites of existing structures were matching in most of the cases and some were lying in the vicinity of the potential sites within a short span of less than $50 \mathrm{~m}$. This showed the potential of this methodology in planning suitable sites for various soil and water conservation structures. 
This approach is less time consuming, more precise and can be utilized for identifying the potential locations for different interventions for large catchments.

\section{CONCLUSIONS}

For finding the suitable locations for different soil and water conservation interventions, different thematic layers of drainage lines, stream orders, soil characteristics, slope and LULC were integrated in GIS and the set of criteria was applied in three stages. The specific locations and number of structures was determined based on preliminary criteria, slope of the land, vertical interval and horizontal interval required between structures. Since, semi-arid rainfed regions have limitations in the runoff potential availability; these locations were further optimized based on the runoff available after storage by the existing structures. The runoff volume available in a normal year after the existing storage from the entire watershed was estimated to be $870,000 \mathrm{~m}^{3}$. Suitable locations for $25 \mathrm{RFDs}, 74$ farm ponds, and 5 check dams were identified. The derived sites were validated using Google Earth and investigated for its suitability with ground truth collected. This methodology is less time consuming, more precise and can be utilized for the planning of large watersheds.

\section{ACKNOWLEDGEMENTS}

The authors wish to thank VS maps for providing the digitized map, National Remote Sensing Centre for LULC map and Modern Architects for Rural India, NGO for assisting in field investigations.

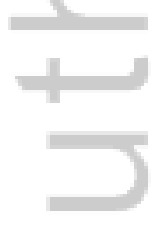

\section{REFERENCES}

Aladenola OO, Adeboye OB. 2010. Assessing the potential of rainwater harvesting. Water Resources Management, 24: 2129-2137.

Amutha R, Porchelvan P. 2009. Estimation of surface runoff in Malattar sub-watershed using 
SCS-CN method. Journal of the Indian Society of Remote Sensing, 37(2):291-304.

Balakrishna HB, Jayaramu KC. 2014. Identification of Potential Sites for Rainwater Harvesting using RS and GIS. International Journal of Surface and Groundwater Management, 2(1):7-9.

Central Ground Water Board, Ministry of Water Resources, Government of India.(CGWB) 2013. Ground Water Brochure - Warangal, Andhra Pradesh (2012-13).

Cheng Q, Koa C, Yuana Y, Gea Y, Zhanga S. 2006. GIS modeling for predicting river runoff volume in ungauged drainages in the Greater Toronto Area, Canada, Computers \& Geosciences, 32: 1108-1119.

Chowdary VM, Ramakrishnan D, Srivastava Y K, Chandran V, Jeyaram A. 2009. Integrated Water Resource Development Plan for Sustainable Management of Mayurakshi Watershed, India using Remote Sensing and GIS. Water Resources Management, 23:1581-1602.

Food and Agriculture Organisation of the United nations (FAO). 2016. Technologies for water harvesting and soil moisture conservation in small watersheds for small-scale irrigation, Irrigation technology transfer in support of food security. Water Reports. (Accessed on 14 May 2016). http://www.fao.org/docrep/w7314e/w7314e0q.html

Geetha K, Mishra SK, Eldho TI, Rastogi AK, Pandey RP. 2007. Modifications to SCS CN method for long- term hydrologic simulation. Journal of Irrigation and Drainage Engineering, 133(5): 475-486.

Integrated Mission for Sustainable Development (IMSD). 1995. Technical guidelines, National Remote Sensing Agency, Hyderabad, India, 1-127.

Anschütz J, Kome A, Nederlof M, Neef R de, Ven T van de. 1997. Water harvesting and soil moisture retention. Agrodok 13. Stoas Digigrafi Printers, Wageningen, the Netherlands. 95pp.

Kadam AK, Kale SS, Pande NN, Pawar NJ, Sankhua RN. 2012. Identifying Potential Rainwater Harvesting Sites of a Semi-arid, Basaltic Region of Western India, Using SCS CN Method. Water Resources Management, 26: 2537-2554.

Kalgapurkar A, Mishra PK, Tripathi KP. 2012. Application of RS and GIS in soil and water conservation measures. Indian Journal of Soil Conservation, 40(3): 190-196.

Kumar MG, Agarwal AK, Bali R. 2008. Delineation of potential sites for water harvesting structures using remote sensing and GIS. Journal of the Indian Society of Remote 
Sensing, 36(4):323-34.

Malekani L, Khaleghi S, Mahmoodi M. 2014. Application of GIS in modeling Zilberchai Basin runoff. The International Archives of Photogrammetry, Remote Sensing and Spatial Information Sciences, 40(2):181-186.

Massuel S, George BA, Venot JP, Bharathi, L, Acharya S. 2013. Improving assessment of groundwater resource sustainability with deterministic modelling - A case study of the semi-arid Musi sub-basin, South India, Hydrogeology Journal, 21(7):1567 - 1580.

Ministry of Water Resources, Government of India (MOWR). 2008. Report of Sub-Committee on Policy and Institutional Framework. National Water Mission under National Action Plan on Climate Change. Comprehensive Mission Document, Volume - II,. http://wrmin.nic.in/writereaddata/nwm28756944786.pdf

Mishra SK, Jain MK, Suresh Babu P, Venugopal K, Kaliappan S. 2008a. Comparison of AMCdependent CN-conversion Formulae. Water Resources Management, 22, 1409-1420

Mishra SK, Pandey RP, Jain M K, Singh VP. 2008b. A rain duration and modified AMCdependent SCS-CN procedure for long duration rainfall-runoff events. Water Resources Management, 22, 861-876.

Nandgude SB, Chavan PB, Mahale DM, Shinde VT. 2014. Study of water harvesting potential in Morna river basin of Maharashtra using remote sensing and geographical information system. Trends in Biosciences, 7(4):309-15.

Nune R, George BA, Teluguntla P, Western AW. 2014. Relating trends in streamflow to anthropogenic influences: A case study of Himayat Sagar catchment, India. Water Resources Management, 28 (6): 1579-1595.

Pandey A, Chowdary VM, Mal BC, Dabral PP. 2011. Remote sensing and GIS for identification of suitable sites for soil and water conservation structures. Land Degradation \& Development, 22(3):359-72.

Pandey A, Sahu AK. 2002. Generation of curve number using remote sensing and geographic information system. Water Resources, Map India Conference 2002, Map India 2002.

Patel DP, Gajjar CA, Srivastava PK. 2013. Prioritization of Malesari mini-watersheds through morphometric analysis: a remote sensing and GIS perspective. Environmental earth sciences, 69(8):2643-56.

Pauw E De, Oweis T, Youssef J. 2008. Integrating Expert Knowledge in GIS to locate biophysical potential for water harvesting: Methodology and a case study for Syria. 
ICARDA, Aleppo, Syria. 59 pp.

Prasad YG, Maheswari M, Dixit S, Srinivasarao Ch, Sikka AK, Venkateswarlu B, Sudhakar N, Prabhu Kumar S, Singh AK, Gogoi AK, Singh AK, Singh YV, Mishra A. 2014. Smart practices and technologies for climate resilient agriculture, ICAR-CRIDA, Hyderabad, pp.76.

Ramakrishnan D, Bandyopadhyay A, Kusuma KN. 2009. SCS CN and GIS based approach for identifying potential water harvesting sites in the Kali Watershed, Mahi River Basin, India. Journal of Earth Systems Science, 118 (4): 355-368.

Ramakrishnan D, Durga Rao KHV, Tiwari KC. 2008. Delineation of potential sites for water harvesting structures through remote sensing and GIS techniques: a case study of Kali watershed, Gujarat, India. Geocarto International, 23:2, 95-108.

Rao K. 2003. Evaluation of watershed management program in Srikakulam district of Andhra Pradesh. Unpublished M.Tech Thesis. Indira Gandhi Agricultural University, Raipur, Chattisgarh.

Rejani R, Rao KV, Osman M, Chary GR, Ch.Srinivasa Rao, Sammi Reddy K, Pushpanjali. 2016. Spatial and temporal estimation of soil loss for the sustainable management of a wet semi-arid watershed cluster. Environmental Monitoring and Assessment, 188 (3):116.

Rejani R, Rao KV, Osman M, Chary GR, Pushpanjali, Sammi Reddy K, Ch.Srinivasa Rao. 2015a. Spatial and temporal estimation of runoff in a semi-arid watershed of Southern India. Environmental Monitoring and Assessment, 187 (8):1-16.

Rejani R, Rao KV, Osman M, Chary GR, Pushpanjali, Sammi Reddy K, Ch. Srinivasa Rao. 2015b. Location specific identification of $i n$-situ soil and water conservation interventions for sustainable management of drylands. Journal of Agrometeorology, 17(1): 55-60.

Saptarshi PG, Raghavendra RK. 2009. GIS based evaluation of micro-watersheds to ascertain site suitability for water conservation structures. Journal of the Indian Society of Remote Sensing, 37(4), 693-704.

Soil Conservation Service, US Department of Agriculture (SCS). 1972. SCS National Engineering Handbook, Section 4. Hydrology, Washington, DC.

Shanwad UK, Patil VC, Gowda HH, Dasog GS, Shashidhar KS. 2011. Generation of water resources action plan for Medak Nala Watershed in India using Remote sensing and GIS technologies. Australian Journal of Basic and Applied Sciences, 5(11): 2209-2218. 
Sharma BR, Paul DK. 1998. Water resources of India. In 50 years of natural resources management research (GB Singh, BR Sharma) Division of Natural Resources Management, ICAR, New Delhi: 31-48.

Singh A. 1974. Selection of structures for soil and water conservation. Soil Conservation Digest, 2(2): 49-53.

Singh JP, Singh D, Litoria PK. 2009. Selection of suitable sites for water harvesting structures in Soankhad watershed, Punjab using remote sensing and geographical information system (RS\&GIS) approach-A case study. Journal of the Indian Society of Remote Sensing, 37(1):21-35.

Soulis KX, Valiantzas JD, Dercas N, Londra PA. 2009. Investigation of the direct runoff generation mechanism for the analysis of the SCS-CN method applicability to a partial area experimental watershed. Hydrological Earth System Science, 13, 605-615.

Srinivasarao Ch, Rejani R, Prasannakumar. 2014. Climate Resilient Agriculture - NICRA experiences to improve the adaptive capacity through sustainable water management. In Proceedings of the National Workshop on Climate Change and Water: Improving WUE. Water and Land Management and Research Institute (WALAMTARI), Hyderabad, pp.930.

Srivastava RK, Sharma HC, Raina AK. 2010. Suitability of soil and water conservation measures for watershed management using geographical information system. Journal of Soil and Water Conservation, 9(3):148-53.

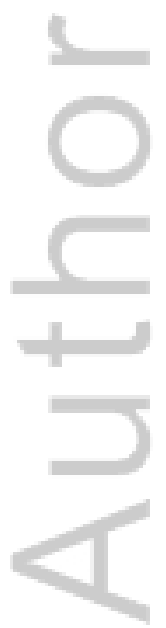




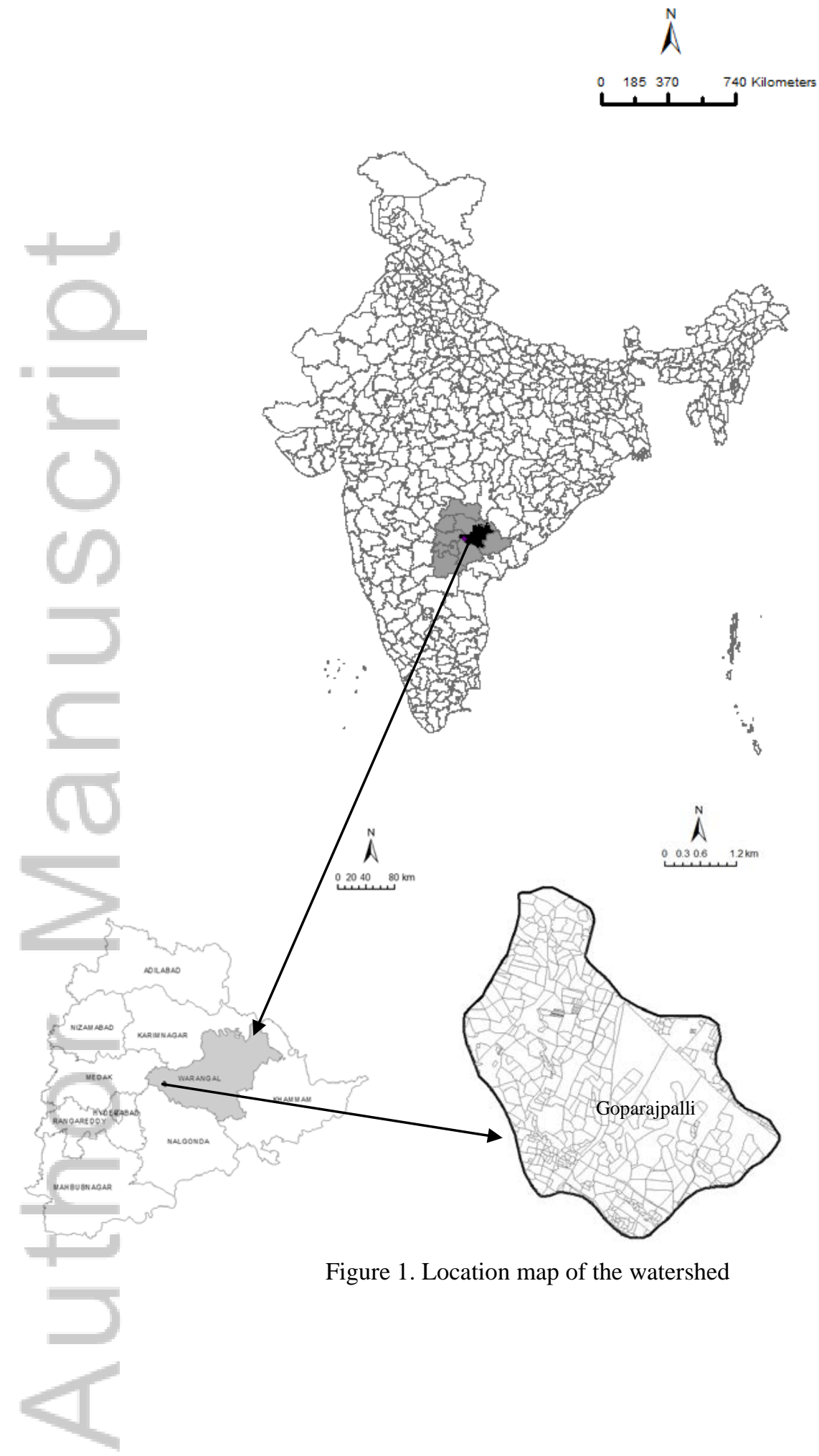

This article is protected by copyright. All rights reserved. 


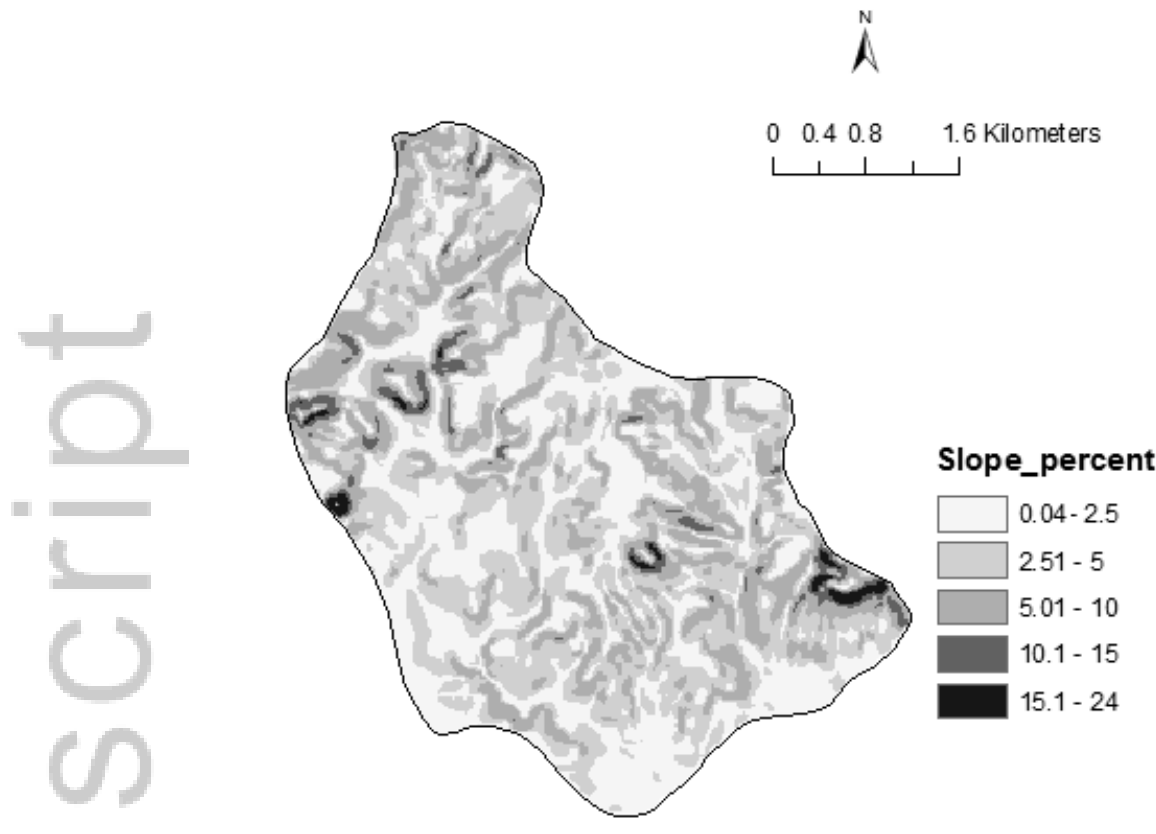

Figure 2. Slope map of Goparajpalli watershed

This article is protected by copyright. All rights reserved. 


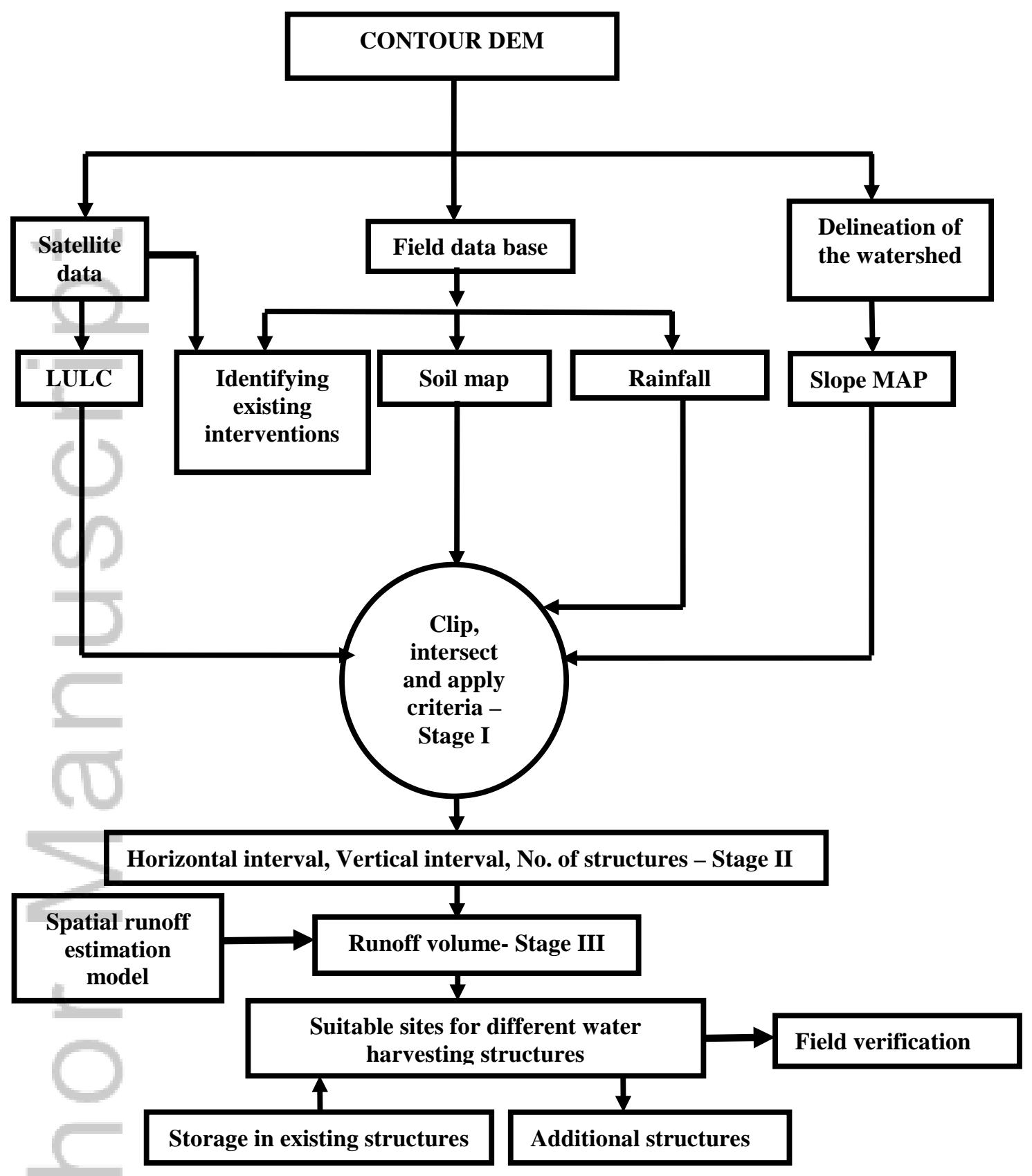

Figure 3. Flow chart for the determination of potential sites for various interventions 


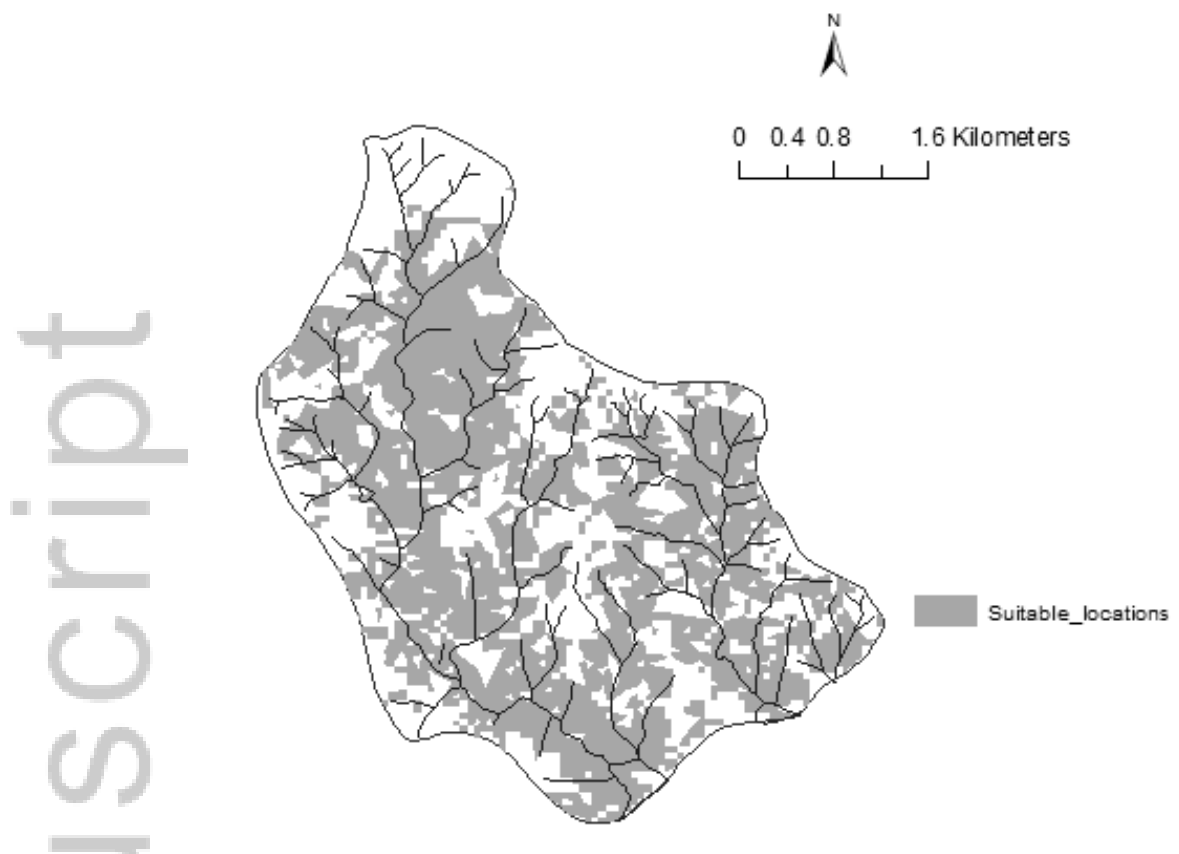

Figure 4. Suitable locations for different soil and water conservation interventions at Stage I

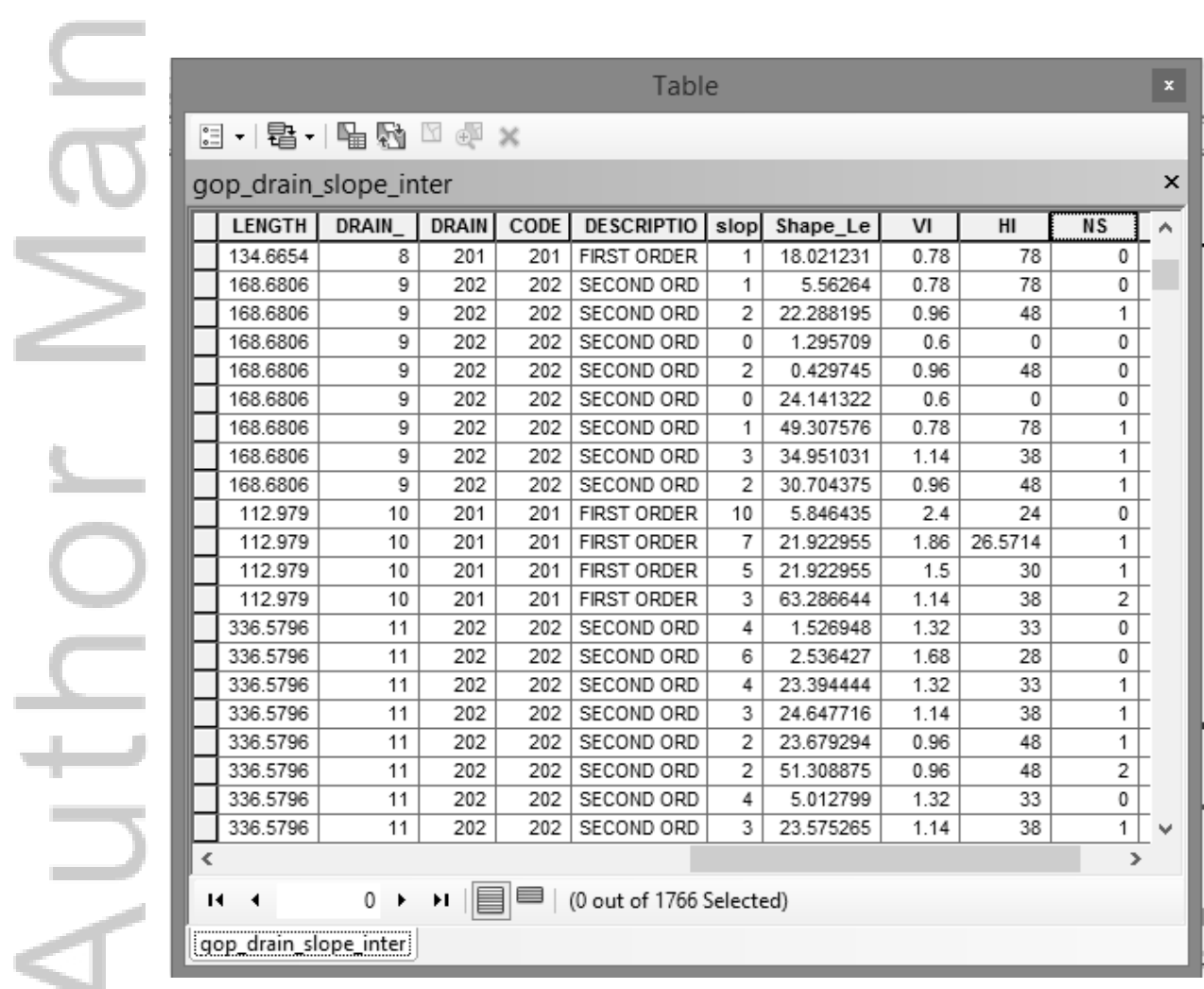

Figure 5. Optimum number of structures (NS) determined at Stage II 


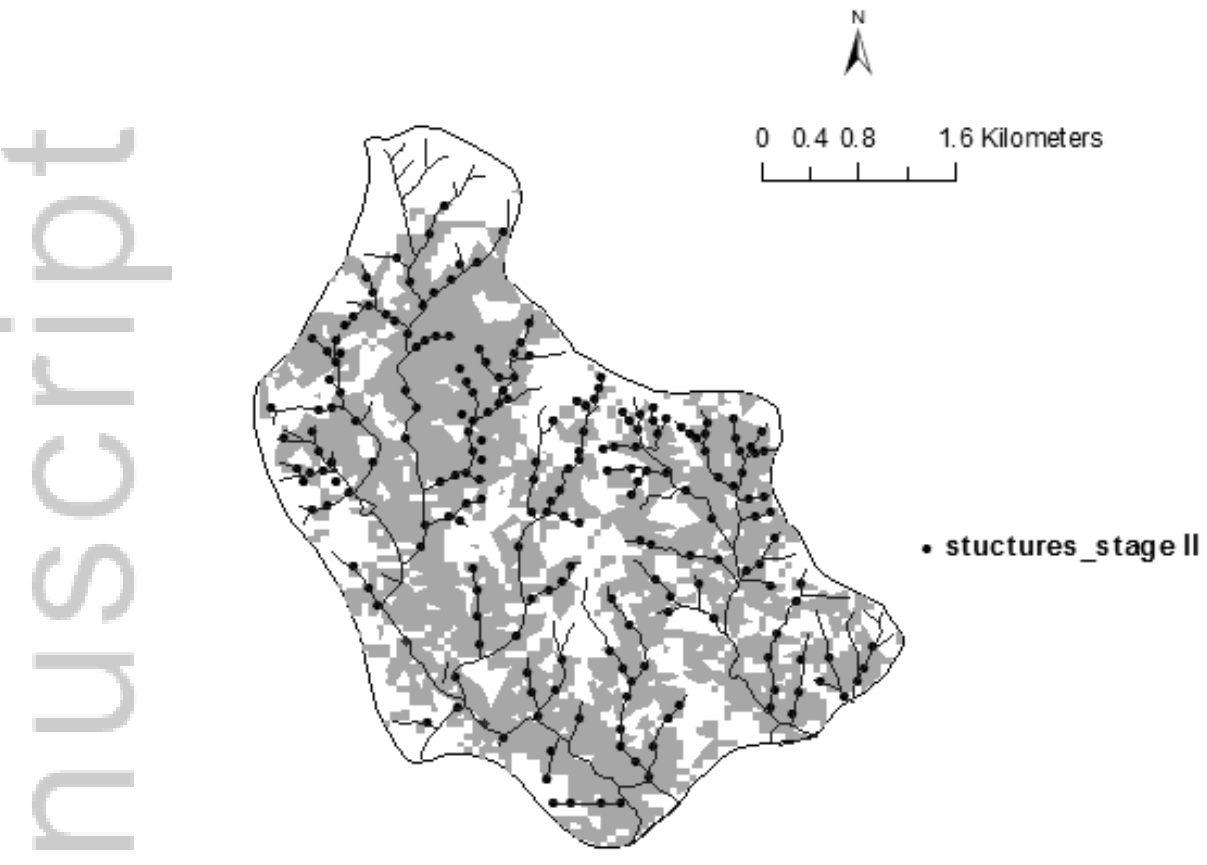

Figure 6. Potential sites for different water harvesting structures for Goparajpalli at Stage II
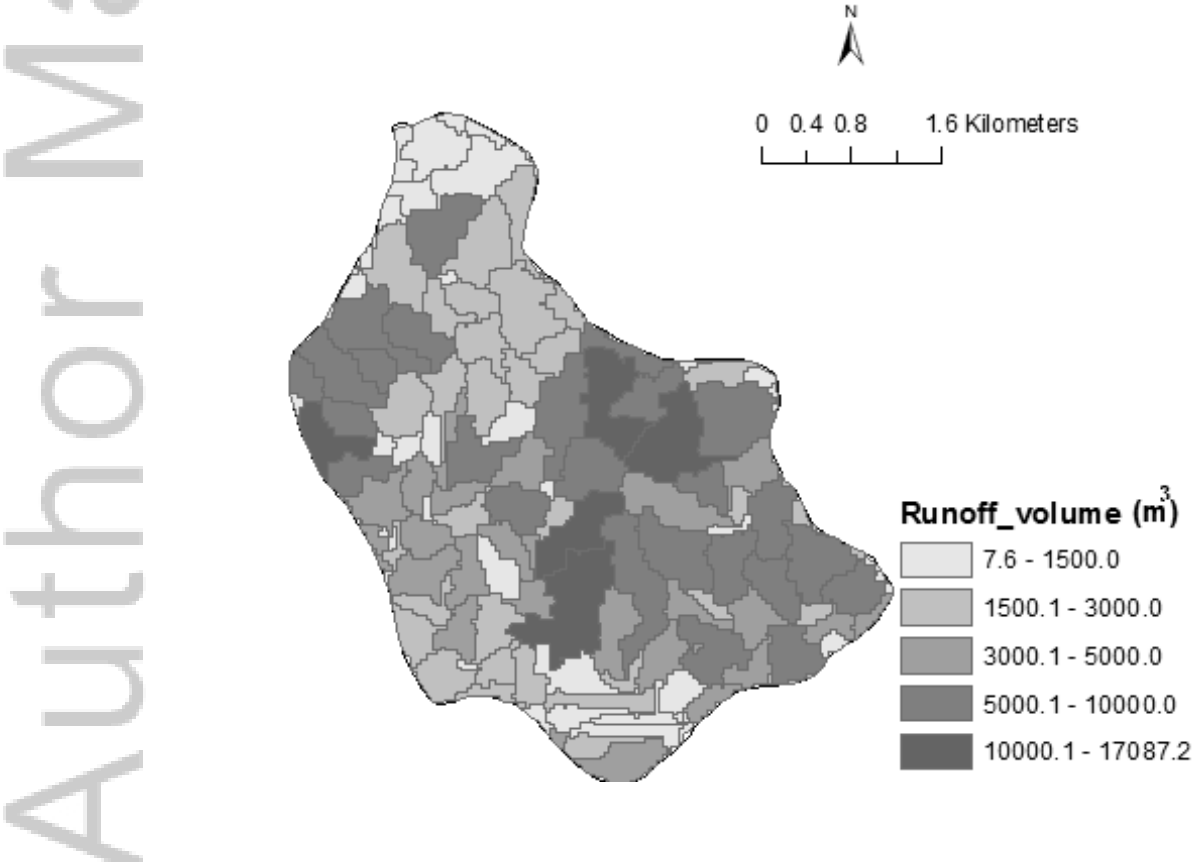

Figure 7. Surplus runoff potential available after storage by the existing structures in the watershed 


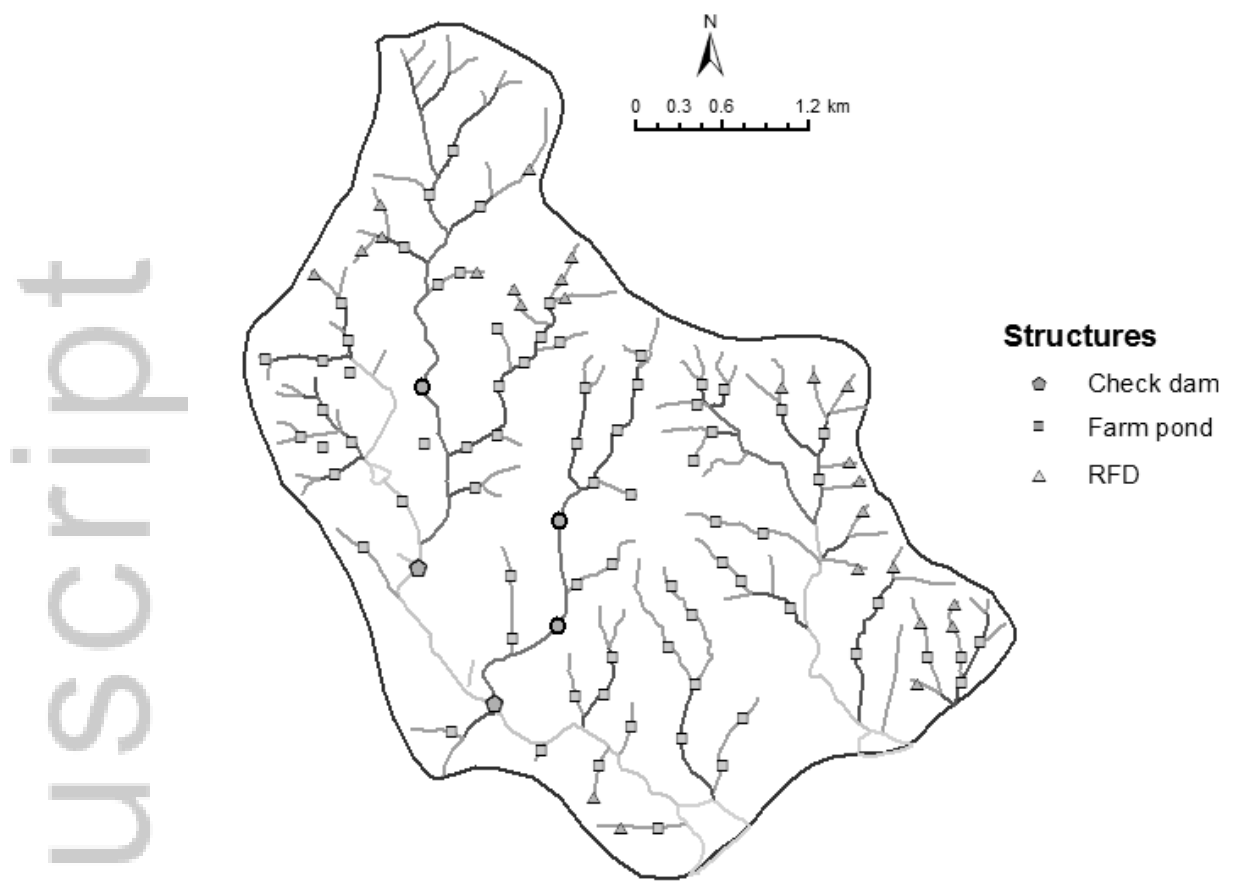

Figure 8. Potential sites determined with the surplus runoff potential available (Stage III)

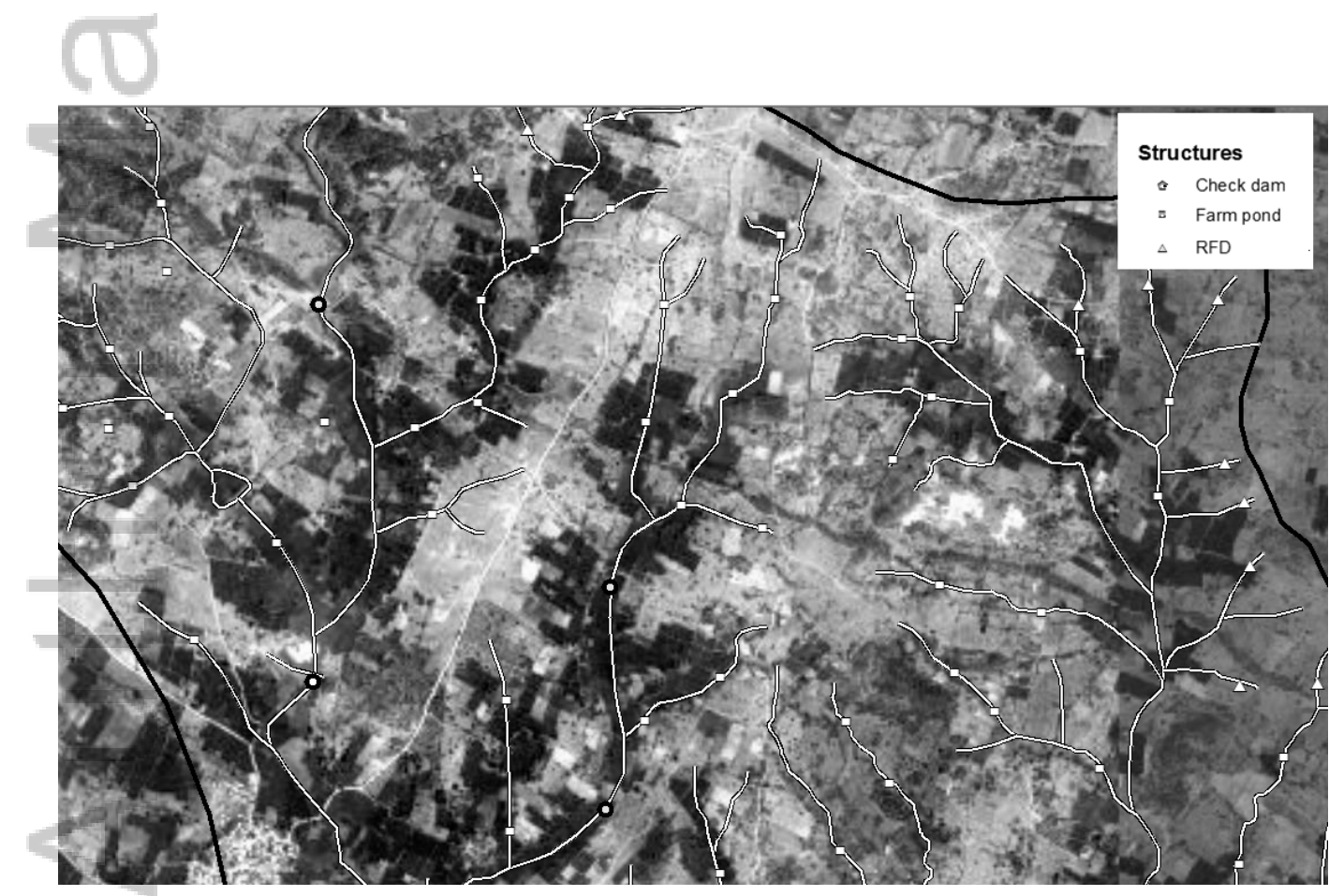

Figure 9. Validation of potential sites for water harvesting structures identified at Goparajpalli watershed 


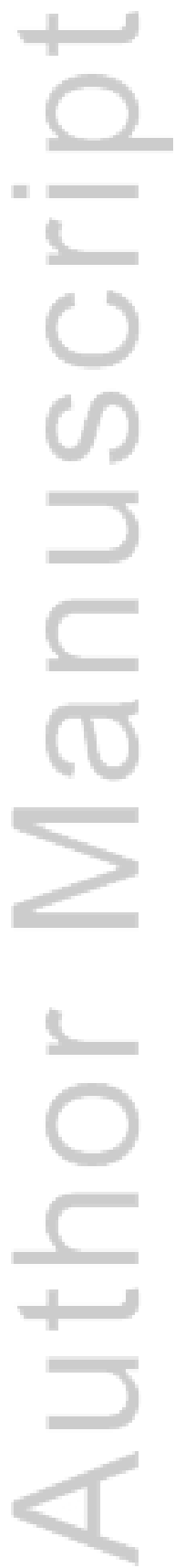

This article is protected by copyright. All rights reserved. 
Table 1. Preliminary site selection criteria for the planning of different water harvesting structures

\begin{tabular}{|c|c|c|c|c|c|c|c|}
\hline Structure & Slope (\%) & Permeability & Runoff coefficient & Stream order & $\begin{array}{l}\text { Watershed } \\
\text { area (ha) }\end{array}$ & Soil type & Rainfall (mm) \\
\hline Farm ponds & $0-5^{\text {(a\&b) }}$ & Low ${ }^{(a \& b)}$ & Medium/high ${ }^{(\mathrm{a} \& \mathrm{~b})}$ & $\begin{array}{l}1-2^{(a \& b)} \text { or without } \\
\text { drains }\end{array}$ & $>1-2^{(\mathrm{a} \& b)}$ & $\begin{array}{l}\text { Clay, sandy clay } \\
\text { loam }^{(b)}\end{array}$ & $>500$ \\
\hline $\begin{array}{l}\text { Check dams (scrubs/ } \\
\text { trees/ river bed) }\end{array}$ & $<15^{(\mathrm{a} \& \mathrm{~b})}$ & Low ${ }^{(a \& b)}$ & Medium/high ${ }^{(a \& b)}$ & $3-4^{(a \& b)}$ & $25^{(\mathrm{a} \& \mathrm{~b})}$ & $\begin{array}{l}\text { Clay, sandy clay } \\
\text { loam }^{(b)}\end{array}$ & $>700$ \\
\hline Check dams (crop land) & $<=3^{(\mathrm{c})}$ & Low ${ }^{(a \& b)}$ & Medium/high ${ }^{(a \& b)}$ & $3^{(\mathrm{c})}$ & $25^{\text {(c) }}$ & $\begin{array}{l}\text { Clay, sandy clay } \\
\text { loam }^{(b)}\end{array}$ & $>700$ \\
\hline $\begin{array}{l}\text { Percolation tanks } \\
\text { (scrub land) }\end{array}$ & $<10^{(\mathrm{a} \& \mathrm{~b})}$ & $\operatorname{High}^{(\mathrm{a} \& \mathrm{~b})}$ & $\operatorname{Low}^{(a \& b)}$ & $1-4^{(a \& b)}$ & $25-40^{(\mathrm{a} \& \mathrm{~b})}$ & Light sandy soil & $>700$ \\
\hline $\begin{array}{l}\text { Percolation tanks (crop } \\
\text { land) }\end{array}$ & $<=3^{\text {(c) }}$ & High $^{(c)}$ & Low ${ }^{(a \& b)}$ & $1-4^{(a \& b)}$ & $25-40^{(\mathrm{a} \& \mathrm{~b})}$ & Light sandy soil & $>700$ \\
\hline
\end{tabular}

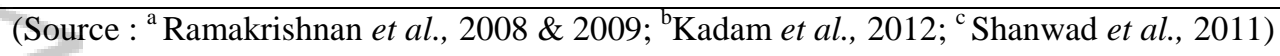

This article is protected by copyright. All rights reserved. 
Table 2. Preliminary site selection criteria for planning of different in-situ soil and water conservation interventions

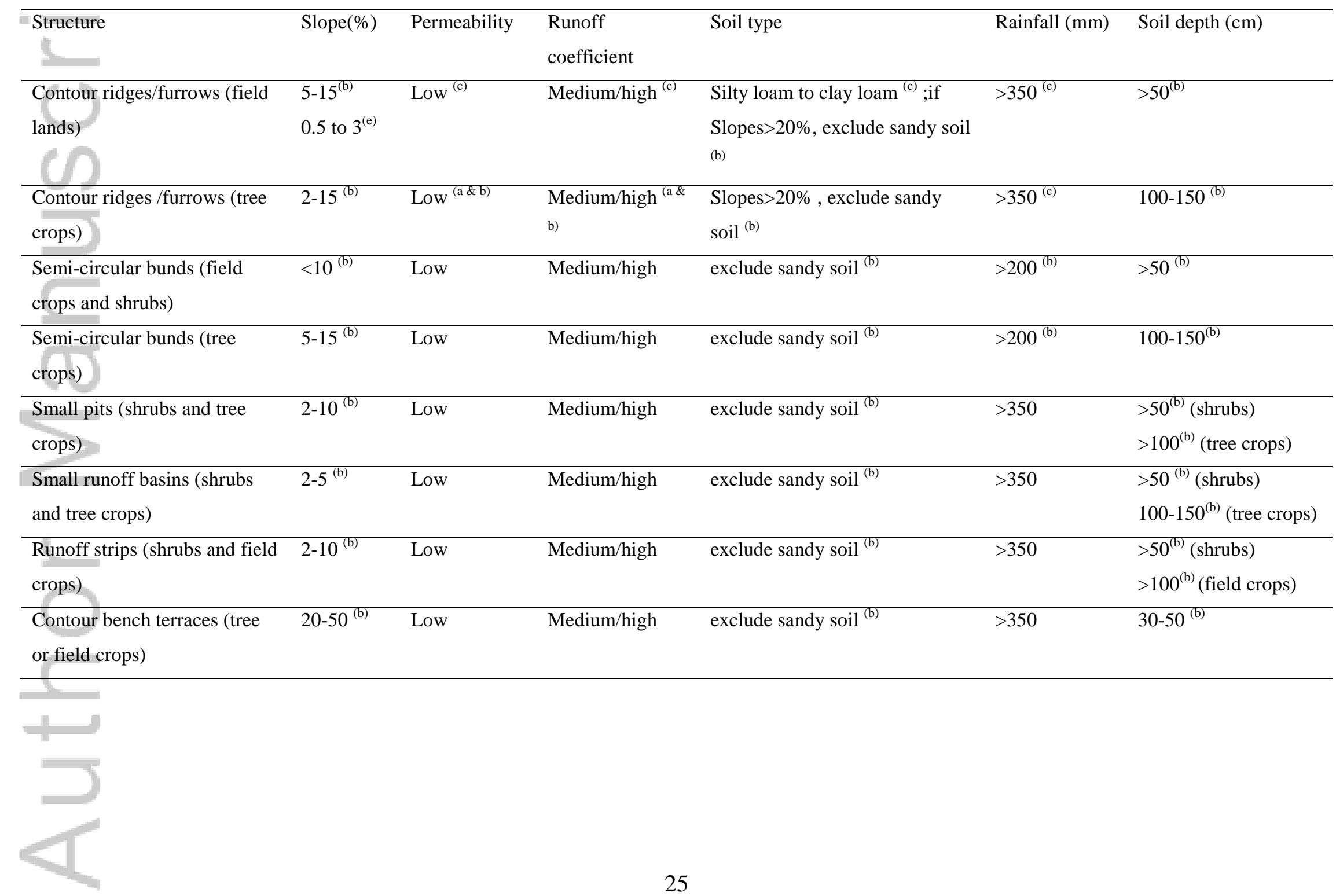

This article is protected by copyright. All rights reserved. 


\begin{tabular}{|c|c|c|c|c|c|c|}
\hline $\begin{array}{l}\text { Stone bunds (tree or field } \\
=\text { crops) }\end{array}$ & 0.5 to $3^{(\mathrm{c})}$ & Low & Medium/high & Clayey soil $^{(\mathrm{c})}$ & $>200^{(\mathrm{c})}$ & $>150^{(\mathrm{c})}$ \\
\hline Contour bunds (field crops) & $1-6^{(a)}$ & $\begin{array}{l}\text { Medium to } \\
\text { high }\end{array}$ & Medium/low & exclude deep clayey soil ${ }^{(a)}$ & $>200^{(c)}$ & $<100^{\text {(c) }}$ \\
\hline Contour bunds (tree crops) & $<=5^{(c)}$ & Low & Medium/high & exclude sandy soil $^{(\mathrm{b})}$ & $>200^{(\mathrm{c})}$ & $>150^{(\mathrm{c})}$ \\
\hline $\begin{array}{l}\text { Contour cultivation and } \\
\text { mulching }\end{array}$ & $<=5^{(\mathrm{d})}$ & Low & Medium/high & exclude sandy soil & $>350$ & $>100^{(\mathrm{d})}$ \\
\hline
\end{tabular}

mulching

(Source : Rejani et al., 2015b; ${ }^{\mathrm{a} S h a n w a d ~}$ et al., 2011; ${ }^{\mathrm{b}}$ Pauw et al., 2008; Justine et al., 1997; ${ }^{\mathrm{d}}$ Kalgapurkar et al., 2012)

This article is protected by copyright. All rights reserved. 


\section{Abbreviations}

CGWB - Central Ground Water Board

DEM - Digital Elevation Model

FAO - Food and Agricultural Organization

GIS - Geographical Information System

IMSD - Integrated Mission for Sustainable Development

LULC - Land Use Land Cover

MOWR - Ministry of Water Resources

RFDs - Rock Fill Dams

SCS-CN-Soil Conservation Service Curve Number

This article is protected by copyright. All rights reserved. 


\section{University Library}

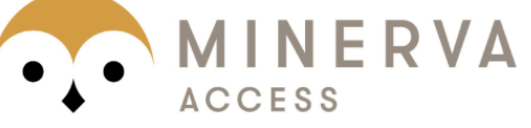

A gateway to Melbourne's research publications

Minerva Access is the Institutional Repository of The University of Melbourne

Author/s:

Rejani, R;Rao, KV;Srinivasa Rao, CH;Osman, M;Sammi Reddy, K;George, B;Pratyusha

Kranthi, GS;Chary, GR;Swamy, MV;Rao, PJ

Title:

Identification of Potential Rainwater-Harvesting Sites for the Sustainable Management of a Semi-Arid Watershed

Date:

2017-04-01

Citation:

Rejani, R., Rao, K. V., Srinivasa Rao, C. H., Osman, M., Sammi Reddy, K., George, B., Pratyusha Kranthi, G. S., Chary, G. R., Swamy, M. V. \& Rao, P. J. (2017). Identification of Potential Rainwater-Harvesting Sites for the Sustainable Management of a Semi-Arid Watershed. Irrigation and Drainage, 66 (2), pp.227-237. https://doi.org/10.1002/ird.2101.

Persistent Link:

http://hdl.handle.net/11343/292340 